\title{
Flooding tolerance of tomato genotypes during vegetative and reproductive stages
}

\author{
Vincent Ezin ${ }^{1,2}$, Robert De La Pena ${ }^{2}$, Adam Ahanchede ${ }^{1}$ \\ ${ }^{1}$ Faculty of Agriculture, University of Abomey-Calavi 01 BP 526 Cotonou, Benin \\ ${ }^{2}$ AVRDC- The World Vegetable Center in Taiwan, , 60 Yi-Min Liao, Shanhua, Tainan-74151, Taiwan \\ *Corresponding author: ishola.vincent@yahoo.com \\ Received: 05 April 2010; Accepted: 09 August 2010
}

\begin{abstract}
A greenhouse experiment was conducted to investigate the effect of flooding on two tomato cultivars and two wild related species. Forty days old tomato plants were subjected to a continuous flooding stress of different durations: 0, 2, 4 and 8 days. Plant pots were placed inside larger plastic pots; they were irrigated with excessive quantity of tap water at $25^{\circ} \mathrm{C}$ so that the level of water above the surface of soil was $15 \mathrm{~cm}$ throughout the flooding period. At the bottom of each plastic pot a drilled hole allowed complete drainage of the pot after flooding. Parameters studied include plant height, number of leaves, leaf length, chlorophyll fluorescence, chlorophyll content, wilting, leaf senescence, adventitious root formation, number of flowers and fruits from cluster 2 to 6 , average weight per fruit, fruit length and width, total fruit weight from cluster 2 to 6 , total yield per plant. LA1579 genotype was more subjected to the deleterious effect of flooding on almost all the parameters studied. Therefore LA1579 genotype is flooding sensitive. Genotypes CLN2498E, and CA4 showed high tolerance to flooding while LA1421 genotype was tolerant to some extent. This experiment provides information that could help in the identification of physiological and agronomical parameters associated with flood-tolerance in vegetables.
\end{abstract}

Key Words: Tomato genotypes, flooding conditions, chlorophyll, growth parameters, yield and yield components

\section{INTRODUCTION}

Flooding is an environmental stress that severely limits crop growth and productivity. It has become a major problem in some parts of the world. Waterlogging and flooding are common in rain-fed ecosystems, especially in soils with poor drainage. Both flooding and waterlogging can seriously reduce yield (Dennis et al., 2000) and they are among the stresses considered by the Food and Agriculture Organization (FAO) and the International Institute for Applied Statistical Research in their estimates of global arable land area and global productivity (Fischer et al., 2001). Flooding can result in yield reduction of up to $10 \%$ (Bange et al., 2004) and $40 \%$ in severe cases (Hodgson and Chan, 1982). As a consequence of disturbed physiological functioning, vegetative and reproductive growth of plants is negatively affected by flooding (Kozlowski, 1984; Gibbs and Greenway, 2003).

Amongst the obvious symptoms of flooding injury is yellowing and death of the leaves, from the lower ones to the stem. This chlorosis seemingly to some extent looks like nitrogen insufficiency, but often forms between four and six days after flooding, much too soon to be caused by nitrogen deficiency. In between twenty-four and forty-eight hours after the soil is flooded, the middle leaves of tomato show epinastic curvature (Kramer, 1951). Soil flooding usually influences plant growth in a negative way. The early senescence of leaves and the retarded growth of shoots in flooded plants is caused by the inhibition of nitrogen $(\mathrm{N})$ uptake, and the consequent redistribution of nitrogen within the shoot (Drew and Sisworo, 
1977). A decrease in the nitrogen concentration in shoots of plant (Hordeum vulgare L.) seedlings can occur rapidly after the onset of flooding and precede leaf chlorosis (Drew and Sisworo, 1977; Wang et al., 1996) and consequently reduces shoot and root growth, dry matter accumulation, and final yield (Kozlowski, 1984; Drew, 1992; Huang et al., 1994a, 1994b; Malik et al., 2002). Roots are also injured by oxygen $\left(\mathrm{O}_{2}\right)$ deficiency and metabolic changes during acclimation to low concentrations of $\mathrm{O}_{2}$ (Drew, 1997). Roots get oxygen for growth and mineral uptake from air pockets in the soil, but, when roots are partially submerged (waterlogged) or completely submerged (flooded), the anoxic conditions prevent root growth and send signals to the rest of the plant to reduce shoot growth and plant productivity (Bennett, 2003). Plants such as rice are tolerant to waterlogging because of their well-developed aerenchyma tissues in the roots and the stem (Xu and Mackill, 1996). Kramer (1951) reported that tomato plants survive flooding conditions through the production of new adventitious roots. He further stated that the resumption of shoot growth might be attributed to a renewed supply of hormone from the new adventitious roots.

Tolerant genotypes to flooding are associated with a complex trait which is linked to many morphological and physiological traits that are under though environmental pressure. Leaf chlorosis after flooding is one of the major indices used by researchers in different crops such as wheat (Triticum aestivum L.) (Cai et al. 1996; Boru et al. 2001), soybean [Glycine max (L.) Merr.] (Reyna et al., 2003), and barley (Hamachi et al., 1990). In tomato, and other plant, flooding stress causes deleterious symptoms such as epinasty, leaf chlorosis, necrosis, and reduced fruit yield (Kuo et al., 1982; Kuo and Chen, 1980).

Plant age, time and duration of flooding, condition of the floodwater, and site characteristics influence significantly flood tolerance among plant species, genotypes and rootstocks (Kozlowski, 1997b). Flood-tolerant plants endure waterlogging by multifaceted interactions of morphological, anatomical, and physiological adaptations. Tolerant genotypes also resist inundation through production of hypertrophied lenticels, aerenchyma tissue, and adventitious roots (Kozlowski, 1997b). In order to increase crop productivity in flooded soils, development of flooding-tolerant lines is required. Therefore, the objective of this study was to investigate the physiological and morphological behavior of four tomato genotypes in flooding conditions that may lead to screening for flooding tolerance in tomato.

\section{MATERIAL AND METHODS}

Experimental site: The experiment was conducted on Tomato (Lycopersicon esculentum Mill.) at AVRDC- World Vegetable Center in Taiwan, Asia.

Plant material: Four tomato genotypes obtained from the AVRDC gene bank: LA1579, CA4, CLN2498E, and LA1421, were used to screen for flooding tolerance. Seeds of these genotypes were sown in seedling trays filled with peat moss and watered daily. Three weeks-old seedlings were transplanted into plastic cylinders $(22 \mathrm{~cm}$ diameter and $50 \mathrm{~cm}$ height) filled with $15 \mathrm{~kg}$ of clay loamy soil and kept in the greenhouse where they were grown to maturity under natural sunlight with a temperature of $15^{\circ} \mathrm{C}-32$ (day) and $10-22^{\circ} \mathrm{C}$ (night). Granule fertilizer (Foliar Nitro-Phoska) containing nitrogen, phosphorus, potassium, magnesium (20-19-19-0.5) was applied at a rate of $2 \mathrm{~g}$ per pot at 3 weeks intervals. Additionally, a mixture of pesticide (Pymetrozine 25\% WP; Benlate 50\% WP; Trigard 75\% WP; Adjuvant and Chlorfuazuron $5 \% \mathrm{EC}$ ) was sprayed weekly to prevent disease and insect infestation.

Chlorophyll fluorescence measurement: Chlorophyll fluorescence parameters were recorded at weekly intervals with a continuous portable OS-30P chlorophyll fluorometer (Opti-Sciences, 8 Winn Avenue Hudson, NH03051). Measurements were made on fully expanded leaflets of the upper canopy after a 60 min dark adaptation period between 7:00 and 10:00 am Taiwan standard time. Dark fluorescence $\mathrm{Fo}$, maximal fluorescence $\mathrm{Fm}$ and photochemical yield $\mathrm{Fv} / \mathrm{Fm}$ (where $\mathrm{Fv}=\mathrm{Fm}-\mathrm{Fo}$ ) were recorded. The $\mathrm{Fv} / \mathrm{Fm}$ ratio is an indicator of plant stress resulting from damage to photosystem II (Björkman, 1987) and indicates if reductions of net $\mathrm{CO}_{2}$ assimilation in stressed plants are the result of photoinhibitory damage to the photosynthetic apparatus.

SPAD chlorophyll content measurement: SPAD chlorophyll content was measured every week using a portable Minolta Chlorophyll Meter SPAD-502. The average of triplicate readings was recorded at each third upper expanded leaflet.

Growth and reproductive measurements: Each week, plant height $(\mathrm{cm})$, leaf length $(\mathrm{cm})$, number of leaves, were 
measured. Plant height, in centimeter, indicates the distance from the base to the apical meristem. Leaf length, in centimeters was the length of the largest leaf. The number of leaves was measured as the number of leaves preceding the harvest.

One week after removing flooding treatment, individual plants was scored for tolerance (TOL) using a modified scale of 0-5 Yeboah et al., (2008), where $0=$ dead plant, $1=100$ $75 \%$ of wilt from tip to the base, $2=74-50 \%$ wilting of leaves from tip to the middle, $3=$ leaves between base and middle undulating, $4=$ recurved leaves margins and $5=$ green plant with no sign of stress. Adventitious Root Formation (ARF) was scored visually - on a 0-3 scale following the methods of Yeboah et al., (2008), where $0=$ none, $1=$ low, $2=$ medium, $3=$ high. A third flooding tolerance score of individual plants (in terms of yellow leaf percentage) was determined using a scale of $1-6$, where, $1=0 \%$ no yellow leaves, $2=10-30 \%$ of leaves were yellow, $3=30-50 \%$ of leaves were yellow, 4 $=50-70 \%$ were yellow, $5=$ when most leaves were yellow, $6=$ when all leaves were yellow, modified from Mohanty and Ong (2003).

Days to flowing and days to maturity were recorded. Days to flowering was measured as the total number of days from sowing to at least one flower opening. Days to maturity were recorded as the total number of days from sowing to at least one fruit ripening (IPGRI, 1996).

Fruit number was determined as the total number of fruit per plant. Fruit setting percentage was computed as the total fruit number divided by the total flower number from clusters two to six on each plant. The number of flowers was counted as the total number of flowers from cluster two to six on each plant tagged during anthesis by considering the cluster that flowers first. Six fruits per plant were used to measured fruit length, width, and weight. The first fruit from each cluster was harvested. Fruit length was Recorded (in $\mathrm{mm}$ ) from stem end to blossom end, to one decimal place, at maturity from clusters two to six on each plant. Fruit width was recorded (in $\mathrm{mm}$ ) as the largest diameter of cross-sectioned fruits to one decimal place, at maturity from clusters two to six on each plant. Fruit length/width ratio was the ratio between the average fruit length and width from clusters two to six on each plant. Fruit weight was the average fruit weight per plant in grams calculated by dividing the total fruit weight by the total fruit number from clusters two to six on each plant. Yield was the total fruit weight in grams of each plant (IPGRI, 1996).
Experimental design and treatment details: The experiment was laid out in a randomized split plot design with flooding treatment as main plot and the genotypes subplot. Treatments were replicated five times. Forty five day old tomato plants were then subjected to flooding stress of different durations $(0,2,4$ and 8 days) by placing plant pots inside larger plastic pots, then irrigating with an excessive quantity of tap water at $25^{\circ} \mathrm{C}$ so that the level of water above the surface of soil was $15 \mathrm{~cm}$ throughout the flooding period. At the bottom of each plastic pot a drilled hole allowed complete drainage of the pot after flooding. The plants growing under normal nonflooded conditions served as a corresponding control.

Statistical analysis: The data collected were subjected to an analysis of variance using statistical analysis system (SAS) to determine the differences among treatments. Means separation was performed by Turkey's test.

\section{RESULTS}

Effect of flooding on chlorophyll fluorescence and SPAD Chlorophyll content: There were no significant differences in $\mathrm{Fm} / \mathrm{Fv}$ between control and flood treatments in genotypes CA4, CLN2498E, and LA1421 (Table 1 and 3). The Fm/Fv ratio range from 0.832 to 0.801 for CLN2498E, 0.826 to 0.795 for CA4 throughout the experiment, and 0.823 to $0.739,0.804$ to 0.798 for LA1421, respectively 2 weeks after flooding and 37 days after the flooding was initiated. Between 2 days and 9 days of flooding treatment, there was no significant difference between control and flooded LA1579 genotype. From day 16 to 37 , significant difference in Fm/ Fv was observed between 8 days of continuous flooding treatment and control with the values of 0.804 and 0.661 for the control and flooded treatments, respectively.

There were no significant differences in SPAD readings between control and flooded CA4, CLN2498E, and LA1421 genotypes during and after flooding (Table 2 and 3 ). Flooding decreased slightly SPAD readings in LA1421 genotype when compared to the control as the days of continuous flooding application increased. After 23 days of water stress, significant difference in SPAD readings for 4 and 8 days of continuous flooding were observed in LA1579 genotype. A week later plants subjected to 4 days of flooding recovered from their chlorophyll content because there was no significant difference between control plants and 4 days of flooded plants. 
Table 1. Effect of flooding on chlorophyll fluorescence

\begin{tabular}{|c|c|c|c|c|c|}
\hline \multirow{2}{*}{$\begin{array}{l}\text { Days after } \\
\text { flooding }\end{array}$} & \multirow{2}{*}{$\begin{array}{l}\text { Duration of } \\
\text { flooding }\end{array}$} & \multicolumn{4}{|c|}{ Genotype } \\
\hline & & CA4 & CIN2498E & LA1421 & LA1579 \\
\hline \multirow{4}{*}{2} & 0 & $0.826 a$ & $0.821 a$ & $0.823 a$ & $0.824 a$ \\
\hline & 2 & $0.815 a$ & $0.832 \mathrm{a}$ & $0.807 a$ & $0.814 a$ \\
\hline & 4 & $0.813 a$ & $0.813 a$ & $0.812 \mathrm{a}$ & $0.820 \mathrm{a}$ \\
\hline & 8 & $0.821 \mathrm{a}$ & $0.814 a$ & $0.797 a$ & $0.781 a$ \\
\hline \multirow{4}{*}{9} & 0 & $0.817 a$ & $0.820 \mathrm{a}$ & $0.822 \mathrm{a}$ & $0.818 \mathrm{a}$ \\
\hline & 2 & $0.808 \mathrm{a}$ & $0.800 \mathrm{a}$ & $0.802 \mathrm{a}$ & $0.809 a$ \\
\hline & 4 & $0.812 \mathrm{a}$ & $0.806 a$ & $0.807 a$ & $0.810 \mathrm{a}$ \\
\hline & 8 & $0.817 \mathrm{a}$ & $0.817 a$ & $0.787 a$ & $0.752 a$ \\
\hline \multirow{4}{*}{16} & 0 & $0.799 a$ & $0.809 a$ & $0.800 \mathrm{a}$ & $0.804 a$ \\
\hline & 2 & $0.795 a$ & $0.801 a$ & $0.742 \mathrm{a}$ & $0.799 a$ \\
\hline & 4 & $0.808 \mathrm{a}$ & $0.799 a$ & $0.739 a$ & $0.796 a$ \\
\hline & 8 & $0.803 a$ & $0.809 a$ & $0.746 \mathrm{a}$ & $0.665 b$ \\
\hline \multirow{4}{*}{23} & 0 & $0.810 \mathrm{a}$ & $0.811 \mathrm{a}$ & $0.806 a$ & $0.814 a$ \\
\hline & 2 & $0.808 \mathrm{a}$ & $0.813 a$ & $0.817 a$ & $0.803 a$ \\
\hline & 4 & $0.815 a$ & $0.813 a$ & $0.797 a$ & $0.797 a$ \\
\hline & 8 & $0.817 a$ & $0.817 a$ & $0.785 \mathrm{a}$ & $0.661 \mathrm{~b}$ \\
\hline
\end{tabular}

Values with the same letter in each column are not significantly different $(p<0.05)$

Table 2. Effect of flooding on SPAD reading (relative chlorophyll content 0.0-99.9)

\begin{tabular}{|c|c|c|c|c|c|}
\hline \multirow{2}{*}{$\begin{array}{l}\text { Days after } \\
\text { flooding }\end{array}$} & \multirow{2}{*}{$\begin{array}{l}\text { Duration of } \\
\text { flooding }\end{array}$} & \multicolumn{4}{|c|}{ Genotype } \\
\hline & & CA4 & CIN2498E & LA1421 & LA1579 \\
\hline \multirow{4}{*}{2} & 0 & $47.84 a$ & $49.46 a$ & $40.54 a$ & $43.96 a$ \\
\hline & 2 & $44.76 a$ & $47.64 a$ & $37.02 \mathrm{a}$ & $43.6 a$ \\
\hline & 4 & $43.42 \mathrm{a}$ & $46.82 a$ & $39.3 a$ & $42.18 \mathrm{a}$ \\
\hline & 8 & $47.72 \mathrm{a}$ & $46.34 a$ & $36.6 a$ & $43.7 a$ \\
\hline \multirow{4}{*}{9} & 0 & $46.82 a$ & $47.36 \mathrm{a}$ & $42.86 a$ & $47.28 \mathrm{a}$ \\
\hline & 2 & $45.06 a$ & $42.76 a$ & $35.48 \mathrm{a}$ & $42.08 a$ \\
\hline & 4 & $45.76 a$ & $47.5 a$ & $39.2 a$ & $41.6 \mathrm{a}$ \\
\hline & 8 & $43.46 \mathrm{a}$ & $46.24 a$ & $36.4 a$ & $42.66 \mathrm{a}$ \\
\hline \multirow{4}{*}{16} & 0 & $48.9 a$ & $45.8 a$ & $40.76 a$ & $45.46 a$ \\
\hline & 2 & $45.8 \mathrm{a}$ & $45.92 \mathrm{a}$ & $36.62 a$ & $39.4 a$ \\
\hline & 4 & $45.48 \mathrm{a}$ & $46.04 a$ & $39.2 \mathrm{a}$ & $38.4 a$ \\
\hline & 8 & $45.38 a$ & $46.78 a$ & $34.08 \mathrm{a}$ & $36.06 a$ \\
\hline \multirow{4}{*}{23} & 0 & $48.98 \mathrm{a}$ & $49.06 \mathrm{a}$ & $40.04 a$ & $45.22 a$ \\
\hline & 2 & $48.16 a$ & $43.62 a$ & $34.98 \mathrm{a}$ & $38.38 a b$ \\
\hline & 4 & $46.06 \mathrm{a}$ & $44.86 a$ & $35.9 \mathrm{a}$ & $32.26 \mathrm{bc}$ \\
\hline & 8 & $47.68 \mathrm{a}$ & $47.18 a$ & $35.62 a$ & $25.9 \mathrm{c}$ \\
\hline
\end{tabular}

Values with the same letter in each column are not significantly different $(p<0.05)$ 
Table 3. Effect of flooding on chlorophyll fluorescence, and content

\begin{tabular}{|c|c|c|c|c|c|c|}
\hline \multirow{2}{*}{ Chlorophyll } & \multirow{2}{*}{$\begin{array}{c}\text { Days after } \\
\text { flooding }\end{array}$} & \multirow{2}{*}{$\begin{array}{l}\text { Duration of } \\
\text { flooding }\end{array}$} & \multicolumn{4}{|c|}{ Genotype } \\
\hline & & & CA4 & CIN2498E & LA1421 & LA1579 \\
\hline \multirow{8}{*}{ Fluorescence } & \multirow{4}{*}{30} & 0 & $0.808 \mathrm{a}$ & $0.808 \mathrm{a}$ & $0.806 a$ & $0.805 a$ \\
\hline & & 2 & $0.799 a$ & $0.809 a$ & $0.781 a$ & $0.792 \mathrm{a}$ \\
\hline & & 4 & $0.815 a$ & $0.809 a$ & $0.796 \mathrm{a}$ & $0.793 a$ \\
\hline & & 8 & $0.798 a$ & $0.811 \mathrm{a}$ & $0.788 \mathrm{a}$ & $0.651 b$ \\
\hline & \multirow{4}{*}{37} & 0 & $0.803 a$ & $0.809 \mathrm{a}$ & $0.804 a$ & $0.807 a$ \\
\hline & & 2 & $0.806 a$ & $0.816 a$ & $0.813 a$ & $0.816 a$ \\
\hline & & 4 & $0.818 \mathrm{a}$ & $0.809 a$ & $0.809 a$ & $0.796 a$ \\
\hline & & 8 & $0.803 a$ & $0.817 a$ & $0.798 \mathrm{a}$ & - \\
\hline \multirow{8}{*}{ Content } & \multirow{4}{*}{30} & 0 & $49.4 a$ & $48.88 \mathrm{a}$ & $42.78 \mathrm{a}$ & $46.18 \mathrm{a}$ \\
\hline & & 2 & $48.48 a$ & $45.02 a$ & $35.6 a$ & $43.5 \mathrm{a}$ \\
\hline & & 4 & $46.66 a$ & $46.08 \mathrm{a}$ & $37.94 a$ & $36.78 a$ \\
\hline & & 8 & $49.28 \mathrm{a}$ & $47.07 a$ & $35.46 a$ & - \\
\hline & \multirow{4}{*}{37} & 0 & $50.88 a$ & $47.64 a$ & $41.32 \mathrm{a}$ & $42.1 \mathrm{a}$ \\
\hline & & 2 & $47 a$ & $44.06 \mathrm{a}$ & $35.76 a$ & $40.84 a$ \\
\hline & & 4 & $46.94 a$ & $45.4 a$ & $37.86 a$ & $35.72 \mathrm{a}$ \\
\hline & & 8 & $49.06 \mathrm{a}$ & $46.9 \mathrm{a}$ & $32.2 \mathrm{a}$ & - \\
\hline
\end{tabular}

Values with the same letter in each column are not significantly different $(p<0.05)$

Effect of flooding on growth parameters: There was decrease in plant height of LA1421 genotype as the days of flooding increased however this was not statistically significant (Figure 1). In contrast there was slight increase in plant height of CLN2498E genotype for 4, and 8 day of continuous flooding, although this was not statistically significant. Significant differences $(P<0.05)$ were observed in the plant height of CA4 and LA1579 genotypes between the control and the flooded plants for 8 days of continuous flooding. 19 days after the continuous 8 flooding days was initiated until their death, plant height of LA1579 genotype significantly differed $(P<0.05)$ when compared to the control. Growth of LA1579 genotype seemed to be more negatively affected by flooding.

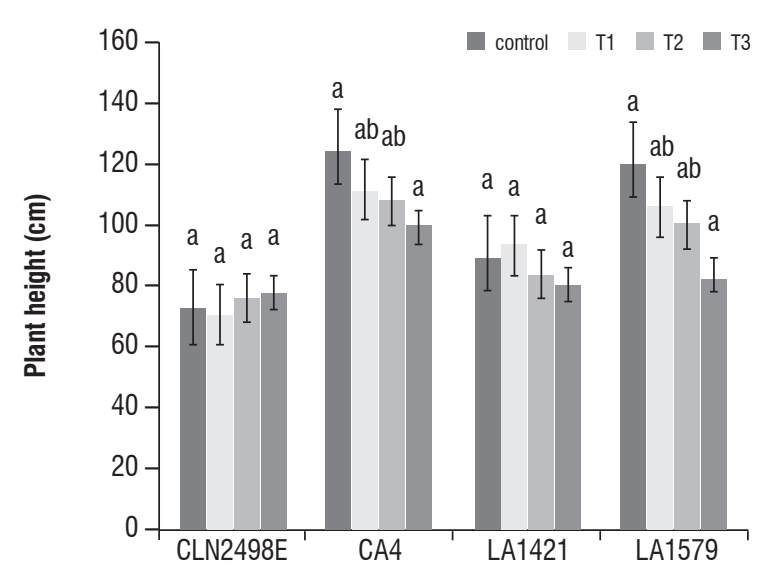

Figure 1. Plant height of different tomato genotypes under flooding conditions. 
The effect of flooding treatment ( $15 \mathrm{~cm}$ above soil surface) on leaf number, and leaf length of CA4 and CLN2498E cultivars was not significantly different $(P>0.05)$ to their respective control. The number of leaves, however, slightly increased as the days of flooding increased with CLN2498E cultivar whereas it decreased slightly with CA4 cultivar due to the changes in plant height. Leaf length, in both cultivars, decreased slightly with the increase in days of continuous flooding. From10 days after the flooding was initiated, significant differences $(P<$
0.05 ) in leaf number of both LA1421 and LA1579 wild related species were observed (Table 4). It is obvious that LA1579 genotype showed high degree of negative response to flooding compared to LA1421. Leaf length (Table 5) significantly differed $(P<0.05)$ between flooded LA1421, LA1579 plants and their respective controls when treated with continuous 8 days of flooding for LA1421 genotype, and with continuous 4 and 8 days of flooding for LA1579 genotype. LA1579 genotype had the largest reduction in leaf length due to flooding conditions.

Table 4: Effect of flooding on leaf number

\begin{tabular}{|c|c|c|c|c|c|}
\hline \multirow{2}{*}{$\begin{array}{l}\text { Days after flooding was } \\
\text { initiated }\end{array}$} & \multirow{2}{*}{ Duration of flooding } & \multicolumn{4}{|c|}{ Genotype } \\
\hline & & CA4 & CIN2498E & LA1421 & LA1579 \\
\hline \multirow{4}{*}{10} & 0 & $20.4 a$ & $16 a$ & $29.8 \mathrm{a}$ & $34.4 \mathrm{a}$ \\
\hline & 2 & $16.6 \mathrm{a}$ & $15.4 \mathrm{a}$ & $22.8 a b$ & $30.4 a b$ \\
\hline & 4 & $16.4 \mathrm{a}$ & $15.4 a$ & $20.6 b$ & $31.2 a b$ \\
\hline & 8 & $15.6 \mathrm{a}$ & $16.5 a$ & $20.6 b$ & $26.2 b$ \\
\hline \multirow{4}{*}{17} & 0 & $23 a$ & $17.2 \mathrm{a}$ & $32.8 \mathrm{a}$ & $41 \mathrm{a}$ \\
\hline & 2 & $20.6 \mathrm{a}$ & $17.8 \mathrm{a}$ & $28.6 a b$ & $31.2 \mathrm{~b}$ \\
\hline & 4 & $19 a$ & $17.9 \mathrm{a}$ & $22.6 b$ & $28.8 \mathrm{~b}$ \\
\hline & 8 & $18.4 \mathrm{a}$ & $19.25 \mathrm{a}$ & $19.4 b$ & $15.8 \mathrm{c}$ \\
\hline \multirow{4}{*}{24} & 0 & $27 a$ & $20.8 \mathrm{a}$ & $37.6 \mathrm{a}$ & $45 a$ \\
\hline & 2 & $24.4 \mathrm{a}$ & $19.8 \mathrm{a}$ & $36.2 \mathrm{a}$ & $37.4 \mathrm{a}$ \\
\hline & 4 & $23.4 \mathrm{a}$ & $21.6 \mathrm{a}$ & $29.4 a b$ & $32.8 \mathrm{a}$ \\
\hline & 8 & $23 a$ & $22.25 a$ & $23.4 b$ & $11.8 \mathrm{~b}$ \\
\hline \multirow{4}{*}{31} & 0 & $28.2 \mathrm{a}$ & $21.6 \mathrm{a}$ & $40.4 \mathrm{a}$ & $45.8 \mathrm{a}$ \\
\hline & 2 & $26.4 \mathrm{a}$ & $21.7 \mathrm{a}$ & $41 a$ & $41.4 \mathrm{a}$ \\
\hline & 4 & $25.4 \mathrm{a}$ & $22.4 a$ & $33.8 \mathrm{ab}$ & $35.6 \mathrm{a}$ \\
\hline & 8 & $26.4 a$ & $24 a$ & $28.25 b$ & - \\
\hline
\end{tabular}

Values with the same letter in each column are not significantly different $(p<0.05)$ 
Table 5. Effect of flooding on leaf length

\begin{tabular}{|c|c|c|c|c|c|}
\hline \multirow{2}{*}{$\begin{array}{l}\text { Days after flooding } \\
\text { was initiated }\end{array}$} & \multirow{2}{*}{ Duration of flooding } & \multicolumn{4}{|c|}{ Genotype } \\
\hline & & CA4 & CIN2498E & LA1421 & LA1579 \\
\hline \multirow{4}{*}{10} & 0 & $41.8 \mathrm{a}$ & $48.6 \mathrm{a}$ & $34.7 \mathrm{a}$ & $36.6 a$ \\
\hline & 2 & $38.8 a$ & $44.6 \mathrm{a}$ & $29.7 a$ & $35.5 a b$ \\
\hline & 4 & $38.5 \mathrm{a}$ & $47.4 \mathrm{a}$ & $31 a$ & $31.4 \mathrm{bc}$ \\
\hline & 8 & $38.1 \mathrm{a}$ & $45.4 a$ & $30.3 a$ & $30 c$ \\
\hline \multirow{4}{*}{17} & 0 & $42.6 \mathrm{a}$ & $49.8 \mathrm{a}$ & $35.2 \mathrm{a}$ & $37 a$ \\
\hline & 2 & $40.6 a$ & $46 a$ & $30.1 a b$ & $35.5 a b$ \\
\hline & 4 & $39.2 \mathrm{a}$ & $47.8 \mathrm{a}$ & $30.6 a b$ & $31.4 b c$ \\
\hline & 8 & $36.6 a$ & $44.8 \mathrm{a}$ & $28 \mathrm{~b}$ & $29.4 \mathrm{c}$ \\
\hline \multirow{4}{*}{24} & 0 & $43.9 \mathrm{a}$ & $49.3 a$ & $35.2 \mathrm{a}$ & $37.5 \mathrm{a}$ \\
\hline & 2 & $40.4 a$ & $46.4 a$ & $30.6 a b$ & $35.2 a b$ \\
\hline & 4 & $39.2 \mathrm{a}$ & $48.1 \mathrm{a}$ & $30.4 a b$ & $32.4 \mathrm{bc}$ \\
\hline & 8 & $37.6 \mathrm{a}$ & $45.5 \mathrm{a}$ & $28.2 b$ & $30 \mathrm{c}$ \\
\hline \multirow{4}{*}{31} & 0 & $43.6 \mathrm{a}$ & $49.8 \mathrm{a}$ & $35.8 \mathrm{a}$ & $36.9 a$ \\
\hline & 2 & $41.2 \mathrm{a}$ & $46.4 \mathrm{a}$ & $30.9 a b$ & $34.2 a b$ \\
\hline & 4 & $40.4 a$ & $48.2 \mathrm{a}$ & $30.1 a b$ & $31.4 \mathrm{~b}$ \\
\hline & 8 & $37.8 \mathrm{a}$ & $45.25 \mathrm{a}$ & $28.2 b$ & - \\
\hline
\end{tabular}

Values with the same letter in each column are not significantly different $(p<0.05)$

Tolerance to flooding: Adventitious root formation, leaf senescence and leaf wilting are presented in Figure 2. There were significant differences in adventitious root formation for 8 days of continuous flooding among genotypes CA4, CLN2498E, LA1421, and LA1579. CLN2498E had produced the highest adventitious roots due to the flooding conditions $(15 \mathrm{~cm}$ above soil surface) while LA1579 had the lowest number of adventitious roots (Figure 2b). Two weeks after flooding was initiated the yellow leaf percentage (leaf senescence) was recorded. Genotype LA1579 responded negatively to flooding in producing the highest yellow leaf percentage (80\%) followed by LA1421 genotype compared to their control plants, respectively (Figure 2c). Flooding treatment had no effect on the leaves of CA4, and CLN2498E cultivars.

CLN2498E, CA4, and LA1579 genotypes showed no leaf wilting under flooding conditions (Figure 2a). LA1421 genotype wilted under flooding conditions, but recovered 2 days after the flooding was initiated.
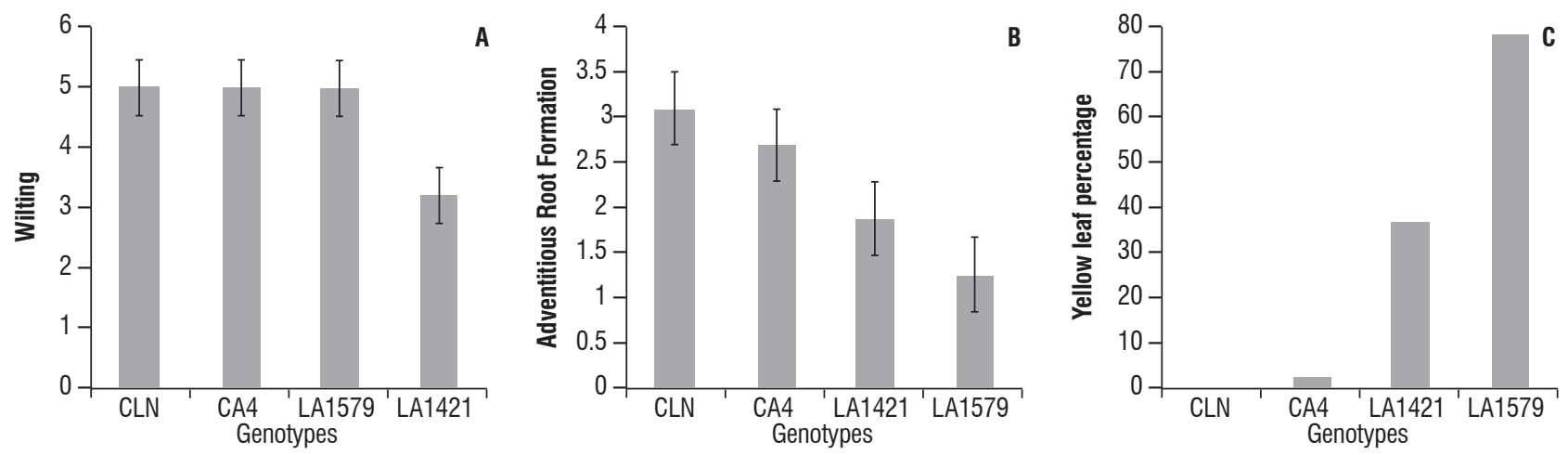

Figure 2. Tolerance parameters determined in different tomato genotypes under 8 days of flooding conditions (15cm above soil surface): (a) leaf wilting, (b) adventitious root formation, (c) leaf senescence. 
Yield and yield components: Table 6 shows that there were significant differences $(P<0.05)$ in days to flowering, and days to maturity among the four genotypes. CLN2498E flowered, matured and set fruit, earlier than genotypes CA4, LA1241, and LA1579.

Table 6. Effect of flooding on days to flowering, days to fruiting, and days to maturity

\begin{tabular}{ccc}
\hline Genotype & Days to flowering & Days to maturity \\
\cline { 2 - 3 } CLN2498E & $50.8 \mathrm{a}$ & $102.14 \mathrm{a}$ \\
CA4 & $55.7 \mathrm{~b}$ & $109.4 \mathrm{~b}$ \\
LA1421 & $54.95 \mathrm{~b}$ & $108.43 \mathrm{~b}$ \\
LA1579 & $56.4 \mathrm{~b}$ & $107.43 \mathrm{~b}$ \\
\hline
\end{tabular}

Values with the same letter in each column are not significantly different $(p<0.05)$
The number of flowers and fruits are presented in Table 7. The number of flowers and fruits in flooded CLN2498E did not differ significantly $(P<0.05)$ from the control at any treatment level. The number of flowers from cluster 2 to 6 in CA4 and LA1421 genotypes was quite constant up to 8 days of flooding, but their fruit number from cluster 2 to 6 was significantly affected $(P<0.05)$ by either 4 or 8 days of flooding. Genotype LA1579 was the most affected by flooding conditions. The number of flowers differed significantly $(P<0.05)$ by 4 days of flooding whereas 2 days of flooding decreased significantly $(P<0.05)$ the number of fruits compared to those of unflooded plants. Eight days of flooding induced the death of all LA1579 plants in the experiment.

Table 7. Effect of flooding on number of flowers and fruits from cluster 2 to cluster 6

\begin{tabular}{|c|c|c|c|c|c|}
\hline & \multirow{2}{*}{ Duration of continuos flooding } & \multicolumn{4}{|c|}{ Genotype } \\
\hline & & CA4 & CIN2498E & LA1421 & LA1579 \\
\hline \multirow{4}{*}{$\begin{array}{l}\text { Number of flowers from } \\
\text { cluster } 2 \text { to cluster } 6\end{array}$} & 0 & $6.9 \mathrm{a}$ & $3.70 \mathrm{a}$ & $6.88 \mathrm{a}$ & $20.44 a$ \\
\hline & 2 & $5.73 a$ & $3.25 \mathrm{a}$ & $7.80 \mathrm{a}$ & $18.66 \mathrm{a}$ \\
\hline & 4 & $5.36 \mathrm{a}$ & $3.50 \mathrm{a}$ & $7.8 \mathrm{a}$ & $13.44 b$ \\
\hline & 8 & $5.38 \mathrm{a}$ & $3.45 a$ & $5.10 \mathrm{a}$ & - \\
\hline \multirow{4}{*}{$\begin{array}{l}\text { Number of fruits from } \\
\text { cluster } 2 \text { to cluster } 6\end{array}$} & 0 & $4.00 \mathrm{a}$ & $3.40 \mathrm{a}$ & $3.52 \mathrm{a}$ & $15.2 \mathrm{a}$ \\
\hline & 2 & 3.33ab & $2.95 a$ & $2.50 a b$ & $9.7 \mathrm{~b}$ \\
\hline & 4 & $2.96 b$ & $3.00 \mathrm{a}$ & $1.65 b c$ & $2.48 \mathrm{c}$ \\
\hline & 8 & $2.00 \mathrm{~b}$ & $3.15 a$ & $0.60 \mathrm{c}$ & - \\
\hline \multirow{4}{*}{ Fruits set percentage } & 0 & $58.97 a$ & $92.59 \mathrm{a}$ & $52.06 a$ & $76.25 a$ \\
\hline & 2 & $57.82 \mathrm{a}$ & $91.37 a$ & $32.05 b$ & $53.78 b$ \\
\hline & 4 & $56.21 a$ & $88.59 a$ & $21.8 \mathrm{bc}$ & $16.45 c$ \\
\hline & 8 & $36.67 \mathrm{~b}$ & $90.75 a$ & $10.96 c$ & - \\
\hline
\end{tabular}

Values with the same letter in each column are not significantly different $(p<0.05)$

Fruit setting percentage of LA1421 and LA1579 genotype decreased significantly $(P<0.05)$ as the day of continuous flooding increased. CLN2498E had the largest fruit setting percentage followed by CA4.

The average weight per fruit, average length, and width per fruit are presented in Table 8. There was no significant difference $(P<0.05)$ in average length, and width per fruit from CLN2498E, CA4, LA1421 genotypes at all treatment levels. The average weight per fruit in CA4, LA1421 genotypes did significantly differ $(\mathrm{P}<0.05)$ after 8 days of flooding when compared to the control plants. There was no significant difference $(P<0.05)$ in average weight from CN2498E but slightly decreased as days of flooding increased when compared to control plants. LA1579 genotype did not bear fruit from cluster 2 to 6 due to flooding conditions. 
Table 8. Effect of flooding on average weight, length, width per fruit from cluster 2 to cluster 6

\begin{tabular}{|c|c|c|c|c|c|}
\hline & & \multicolumn{4}{|c|}{ Genotype } \\
\hline & & CA4 & CIN2498E & LA1421 & LA1579 \\
\hline \multirow{4}{*}{ Average weight per fruit } & 0 & $29.96 a$ & $26.58 \mathrm{a}$ & $2.30 \mathrm{a}$ & $3.89 \mathrm{a}$ \\
\hline & 2 & 18.19ab & $23.67 a$ & $1.00 \mathrm{ab}$ & - \\
\hline & 4 & $13.51 \mathrm{ab}$ & $23.23 a$ & $0.85 a b$ & - \\
\hline & 8 & $7.59 \mathrm{~b}$ & $19.73 a$ & $0.58 \mathrm{~b}$ & - \\
\hline \multirow{4}{*}{ Average length per fruit } & 0 & $1.28 \mathrm{a}$ & $2.20 \mathrm{a}$ & $0.42 \mathrm{a}$ & $0.41 \mathrm{a}$ \\
\hline & 2 & $0.89 \mathrm{a}$ & $2.06 a$ & $0.19 \mathrm{a}$ & - \\
\hline & 4 & $0.66 \mathrm{a}$ & $1.98 \mathrm{a}$ & $0.18 \mathrm{a}$ & - \\
\hline & 8 & $0.44 a$ & $1.77 \mathrm{a}$ & $0.21 \mathrm{a}$ & - \\
\hline \multirow{4}{*}{ Average width per fruit } & 0 & $1.30 \mathrm{a}$ & $1.96 \mathrm{a}$ & $0.49 \mathrm{a}$ & 0.46 \\
\hline & 2 & $0.95 a$ & $2.02 \mathrm{a}$ & $0.21 \mathrm{a}$ & - \\
\hline & 4 & $0.66 a$ & $1.73 a$ & $0.23 a$ & - \\
\hline & 8 & $0.45 a$ & $1.60 \mathrm{a}$ & $0.13 a$ & - \\
\hline
\end{tabular}

Values with the same letter in each column are not significantly different $(p<0.05)$

The total fruit weight from cluster 2 to 6 and the total yield from CLN2498E did not differ significantly $(P<0.05)$ when compared to the control plants (Table 9).

There was no significant decreased $(P<0.05)$ up to 4 days of continuous flooding in total fruit weight from cluster 2 to 6 and total yield per plant from CA4 but they were significantly affected $(P<0.05)$ after 8 days of continuous flooding.

Two, four, and eight days of continuous flooding significantly decreased $(P<0.05)$ total fruit weight and total yield from LA1421 genotype compared to the control plants.

Table 9. Effect of flooding on total fruit weight from cluster 2 to 6 and total yield per plant

\begin{tabular}{|c|c|c|c|c|c|}
\hline & \multirow{2}{*}{ Duration of flooding (day) } & \multicolumn{4}{|c|}{ Genotype } \\
\hline & & CA4 & CIN2498E & LA1421 & LA1579 \\
\hline \multirow{4}{*}{ Total fruit weight from cluster 2 to cluster $6(\mathrm{~g})$} & 0 & $384.17 a$ & $577.09 \mathrm{a}$ & $31.72 \mathrm{a}$ & $19.67 a$ \\
\hline & 2 & $270.46 a b$ & $545.38 \mathrm{a}$ & $10.16 b$ & - \\
\hline & 4 & $162.63 a b$ & $487.23 a$ & $9.58 b$ & - \\
\hline & 8 & $74.63 b$ & $443.10 \mathrm{a}$ & $8.79 b$ & - \\
\hline \multirow{4}{*}{ Yield per plant (g) } & 0 & $626.47 a$ & $748.56 \mathrm{a}$ & $97.46 a$ & $19.74 a$ \\
\hline & 2 & $435.82 \mathrm{ab}$ & $699.05 a$ & $45.91 b$ & $0.47 \mathrm{~b}$ \\
\hline & 4 & $285.11 a b$ & $595.17 a$ & $23.13 b c$ & $0.26 b$ \\
\hline & 8 & $192.75 b$ & $577.72 \mathrm{a}$ & $10.18 \mathrm{c}$ & - \\
\hline
\end{tabular}

Values with the same letter in each column are not significantly different $(p<0.05)$

Genotype LA1579 failed to bear total fruit weight from cluster 2 to 6 and after 2, 4, and 8 days of continuous flooding. The total yield from LA1579 decreased significantly $(\mathrm{P}<0.05)$ as the days of flooding increased, and no fruit was harvested at 8 days of flooded plants due to the deleterious effect of flooding.

The adverse effect of flooding in term of percentage reduction in total yield of CLN2498E, CA4, LA1421, LA1579 
genotypes were $22.82 \%, 69.235 \%, 89.55 \%$, and $100 \%$ respectively, for 8 days of continuous flooding (with $15 \mathrm{~cm}$ water above soil surface).

\section{DISCUSSION}

Tomato, an important vegetable worldwide is considered to be sensitive to flooding conditions (Iden, 1956, Bray et al., 2001). It has been suggested that lack of oxygen is the main problem associated with flooding (Armstrong, 1979; Jackson and Drew, 1984; Kozlowski, 1984). In LA1579, flooding significantly reduced $(\mathrm{P}<0.05)$ chlorophyll fluorescence $(\mathrm{Fv} /$ Fm) from day 16 after the flooding was initiated, meanwhile in CA4, CLN2498E, and LA1421 flooding did not negatively affect chlorophyll fluorescence for 8 days of continuous flooding. Fv/Fm values of CA4, CLN2498E, and LA1421 genotypes were within the range of 0.781 to 0.832 which are associated with healthy, non-stress, evergreen plants (Demming and Björkman, 1987; Maki and Columbo, 2001; Percival, 2004; Percival, 2005). The significant reduction ( $P<$ 0.05 ) in chlorophyll fluorescence of LA1579 genotype seemed to show that there is a loss in the yield of PSII photochemistry as a result of reduction of photosynthetic rate

There was no significant difference in chlorophyll content of CA4, CLN2498E, and LA1421, although it decreased as days of flooding increased in LA1421 genotype. In LA1579, chlorophyll content differed significantly $(P<0.05)$ for 8 days of continuous flooding compared to the control. Conaty et al., (2008) reported that there was variation in SPAD readings in cotton cultivars under waterlogging, henceforth SPAD readings is a potential methodology to differentiate cultivars in their tolerance to flooding. The differing response of genotypes in term of chlorophyll content and chlorophyll fluorescence, suggest the possibility of using both parameters to screen tomato plant for flooding tolerance.

Total plant height, number of leaves, and leaf length from flooded CLN2498E and CA4 genotypes did not differ significantly $(P<0.05)$ when compared to their control plants whereas in LA1421 and LA1579 there were significance different $(P<0.05)$ among treatment for 4 and 8 days of continuous flooding for number of leaves and leaf length. The data obtained indicates that LA1421 and LA1579 genotypes were negatively affect by flooding conditions. The negative effect of flooding in plant growth, leaf length, and number of leaves from LA1579 genotype could be due to reduction of photosynthetic rate. Reduced plant growth due to flooding was also observed in Annona species (Nunex-Elisea, 1999), Panicum antidotale (Ashraf, 2003), Paspalum dilatatum (Vasellati, 2001) and Genipa americana seedlings (Mielke, 2003), tomato (Walter, 2004); all of these plant species showed growth reduction to varying extents in waterlogged conditions.

CLN2498E and CA4 genotypes exhibited high adventitious root formation above soil surface compared to LA1421, and LA1579. This could be due to their ability to withstand the negative effect of flooding and also to increase water as well as mineral uptake and compensate for loss of the original roots. Hsiao (1973) reported that flooding stress reduces plant absorption of inorganic nutrients. As a consequence, the adventitious roots of CLN2498E and CA4 genotypes can obtain oxygen from air and absorb nutrients; this characteristic may play an important role in its adaptation to flooding conditions. In a similar study on tomato, Walter et al., (2004) demonstrated that tomato had the most vigorous adventitious root growth compared to cucumber, zucchini and bean. Mano and omori (2007) reported that Dicotyledonous plants (e.g., soybean and tomato) generally form taproot system but develop adventitious roots under flooding conditions (McNamara and Mitchell, 1990; Bacanamwo and Purcell, 1999). This characteristic allows the root system to obtain oxygen directly from the air because the adventitious roots formed in the soil and even at the soil surface. The importance of adventitious root formation during flooding has been previously reported for barley (Stanca et al., 2003) and Italian ryegrass (Tase and Kobayashi, 1992).

We hypothesize that the yellowing of the plant followed by the death of the LA1579 plants might be due to toxic substances moving from the soil through roots to the leaves. Kramer (1951) reported that the yellowing and death of the lower leaves of tomato plants may to some extent be associated with by desiccation, but most likely resulting from poisoning by toxic substances moving up from the dying roots. These substances might be evading from dying cells, or formed by microorganisms on the roots or in the soil. He further stated that under anaerobic conditions there is much greater possibility of the production of reduced compounds such as nitrites and sulphides which are toxic to roots and, they are poison to the leaves if carried upward in large quantities.

CLN2498E genotype significantly flowered, set fruits and matured earlier compared to other genotypes, this 
suggests that this genotype could be a way out of avoiding the deleterious effect of flooding and could be beneficial for the implementation of early high yields under flooding conditions.

The significant reduction $(\mathrm{P}<0.05)$ in number of flowers, fruits from cluster 2 to 6 , fruit length, fruit width, average weight per fruit, and total fruit weight from cluster 2 to 6 , total yield from LA1579 could be due to two factors based on the data obtained from this study: the inhibition of photosynthesis and the adverse effect of flooding conditions. The inhibition of yield and yield components in LA1421 genotype was not pronounced as in LA1579 (Tables 7, 8, 9). This is consistent with Kozlowski's work (1997) that flooding of soil often prevents flower bud initiation, anthesis, fruit set, and fruit enlargement in flood-intolerant species. It also induces early abscission of flowers and fruits. The extent of the alteration of reproductive growth varies with plant species and genotype and with the time and duration of flooding. There was no significant difference in yield and yield components of CLN2498E between treatments, but slightly reduced as the days of continuous flooding increased. Reductions in yield were also associated with fewer and smaller fruits. It could be linked to fruitshed plant before harvest. Fruit setting percentage in flooded CLN2498E, CA4, LA1421, LA1579 genotypes were $91.30 \%, 50 \%, 11.76 \%$, and $0 \%$ respectively for 8 day of continuous flooding (with $15 \mathrm{~cm}$ water above soil surface). CLN2498E bore much more fruits than others. Abbott and Gough (1987a) reported that fruit set in flooded V. corymbosum was decreased by $45 \%$.

Under prolonged flooding conditions, flood-intolerant LA1579 plants drastically reduced their morphological and physiological activity and were killed in a short time, meanwhile in flood-tolerant CLN2498E, and CA4 plants withstood the harmful effect of flooding by maintaining their morphological and physiological activities intact and by producing a larger yield.

\section{CONCLUSION}

The findings of this work revealed that: (i) chlorophyll fluorescence and SPAD readings (relative chlorophyll content) are good tools in the selection of flooding tolerance in tomato; (ii) flood tolerant species are able to produce a lot of adventitious roots and high fruit yield; (iii) CLN2498E and CA4 genotypes were highly, and LA1421 moderately tolerant to flooding, and LA1579 intolerant to flooding; (iv) these flood tolerant genotypes could be used as good candidate lines in molecular breeding program to establish definite relation with chlorophyll fluorescence, chlorophyll content, yield and yield components.

Acknowledgements: The authors are thankful to GTZ and AVRDC-The World Vegetable Center for funding and supporting this work. We also thank Dr. Ledesma Dolores for statistical analysis and Joyce.

\section{REFERENCES}

Abbott, J.D. and Gough, R.E. (1987a). Reproductive response of the high bush blueberry to root zone flooding. Hortscience, 22: 40--42.

Arsmtrong, W. (1979). Aeration in higher plants. Advance in Botany Research, 7: 226-332

Ashraf, M. (2003). Relationships between leaf gas exchange characteristics and growth of differently adapted populations of Blue panicgrass (Panicum antidotale Retz.) under salinity or waterlogging. Plant Sci. 166: 69 - 75.

Bacanamwo, M. and Purcell, L.C. (1999). Soybean root morphological and anatomical traits associated with acclimation to flooding. Crop Sci. 39: 143149.

Bange, M.P., Milroy, S.P., and Thongbai, P. (2004). Growth and yield of cotton in response to waterlogging. Field Crops Res. 88: 129-142.

Baruch, Z. (1994). Responses to drought and flooding in tropical forage grasses. Plant and Soil: 164(1):87-96.

Bennett, J. (2003). Increased water productivity through Plant Breeding. CAB International: 103-126

Boru, G., van Ginkel, M., Kronstad, W.E. and Boersma, L. (2001). Expression and inheritance of tolerance to waterlogging stress in wheat. Euphytica, 117:91-98.

Bray E.A., Bailey-Serres J. and Weretilnyk, E. (2001) Responses to abiotic stresses. In: Buchanan, B.B., Gruissem, W. and Jones RL (eds.) Biochemistry and Molecular Biology of Plants. American Society of Plant Physiologist, Rockville, MD, pp 1158-1203

Cai, S.B., Cao, Y. and Fang, X.W. (1996). Studies on the variability and combining ability of waterlogging tolerance in common wheat. Jiangsu $\mathrm{J}$. Agric Sci. 12:1-5.

Carsten Jaeger (2008). Ecophysiological studies on the flood tolerance of common ash (Fraxinus excelsior L.) - Impact of root-zone hypoxia on central parameters of $\mathrm{C}$ metabolism. PhD thesis, Albert-Ludwigs-Universität Freiburg im Breisgau, Germany. Pp. 3.

Conaty, W.C., Tan, D.K.Y., Constable, G.A., Stton, B.G., Field, D.J., and Mamum, E.A. (2008). Genetic variation for waterlogging tolerance in cotton. J. Cotton Sci. 12: 53-61.

Crawford, R.M.M. (1967). Alcohol dehydrogenase activity in relation to flooding tolerance in roots. J. Exp. Bot., 18(3):458-464.

Demming, B. and Björkman, 0. (1987). Comparison of the effect of excessive light on chlorophyll fluorescence $(77 \mathrm{~K})$ and photon yield of $\mathrm{O}_{2}$ evolution in leaves of higher plants. Planta, 171: 171-184.

Dennis, E.S., Dolferus, R. Ellis, M. Rahman, M., Wu, Y. Hoeren, F.U. Grover, A. Ismond, K.P. Good, A.G. and Peacock, W.J. (2000). Molecular strategies for improving waterlogging tolerance in plants. J. Exp. Bot. 51: 89-97.

De Simone, O., Muller, E., Junk, W.J. and Schmidt, W. (2002). Adaptations of central amazon tree species to prolonged flooding: root morphology and leaf longevity. Plant Biol. (Stuttgart), 4:515-522. 
Drew, M.C. and Sisworo, E.J. (1977). Early effects of flooding on nitrogen deficiency and leaf chlorosis in barley. New Phytol. 79:567-571

Drew, M. C. (1992). Soil aeration and plant root metabolism. Soil Sci. 154:259-268.

Drew, M.C. (1997). Oxygen deficiency and root metabolism: Injury and acclimation under hypoxia and anoxia. Ann. Rev. Plant Physiol. Plant Mol. Biol., 48:223-250.

Fischer, G., Shah, M., van Velthuizen, H. and Nachtergaele, F.O. (2001). Global Agro-ecological Assessment for Agriculture in the 21st Century. International Institute for Applied Systems Analysis, Laxenburg, Austria, 33 pp.

Gibbs, J. and Greenway, H. (2003). Mechanisms of anoxia tolerance in plants. I. Growth, survival and anaerobic catabolism. Funct Plant Biol, 30:1-47.

Hodgson, A.S. and Chan, K.Y. (1982). The effect of short term waterlogging during furrow irrigation of cotton in a cracking grey clay. Austral J Agr Res, 33:109-116.

Hsiao, T.C. 1973. Plant responses to water stress. Ann. Rev. Plant Physiol. 24:519-570

Huang, B.R., Johnson, J.W., Nesmith, S., and Bridges, D.C. (1994a). Growth, physiological and anatomical responses of two wheat genotypes to waterlogging and nutrient supply. J. Exp. Bot. 45: 193-202.

Huang, B.R., Johnson, J.W., Nesmith, S. and Bridges, D.C. (1994b). Root and shoot growth of wheat genotypes in response to hypoxia and subsequent resumption of aeration. Crop Sci. 34:1538-1544.

Iden, T. 1956. Effect of oxygen concentration in the soil aeration on growth and nutrient absorption of fruit vegetables. J. Jpn. Soc. Hort. Sci. 25:85-93.

IPGRI (1996). Descriptors for tomato (Lycopersicon spp). Rome

Jackson M.B. and Drew M.C. (1984). Effect of flooding on growth and metabolism of herbaceous plants. In Kozlowski T.T., flooding and plant growth. New York: Academic Press, 47-128.

Johnson, J.R., Cobb, B.G. and Drew M.C. (1994). Hypoxic induction of anoxia tolerance in roots of Adh 1 null mutant Zea maize L. Plant Physiol. 105: 61-67.

Keeley, J.E. (1979). Population differentiation along a flood frequency gradient: Physiological adaptations to flooding in Nyssa sylvatica. Ecol. Monogr., 49(1):89-108.

Kozlowski, T.T. (1984). Extent, causes, and impact of flooding. In Kozlowski TT, flooding and plant growth. New York: Academic Press, 1-7.

Kozlowski, T.T. (1997). Response of woody plants to flooding and salinity. Tree Physiol. Monogr. 1: 1-29.

Kozlowski, T.T. and Pallardy, S.G. (1997b). Growth control in woody plants. Academic Press, San Diego.

Kramer, P.J. (1951). Causes injury to plants resulting from flooding of the soil. Plant Physiol. 26:722-736.

Kuo, C.G. and B.W. Chen. 1980. Physical responses of tomato cultivars to flooding. J. Amer. Soc. Hort. Sci. 105:751-755.

Kuo, C.G., Tsay, J.S., Chen, B.W., and Lin, P.Y. 1982. Screening for flooding tolerance in the genus Lycopersicon. HortScience, 17(1):76-78.

Maki, D.S. and Columbo, S.J. (2001). Early detection of the effects of warm storage on conifer seedlings using physiological tests. Forest Ecol. Manag. 154: $237-249$

Malik, A.I., Colmer, T.D., Lambers, H., Setter, T.L. and Schortemeyer, M. (2002). Short-term waterlogging has long-term effects on the growth and physiology of wheat. New Phytol. 153: 225-236.

Mano, Y. and Omori, F. (2007). Breeding for flooding tolerant maize using "teosinte" as a germplasm resource. Plant Root 1: 17-21. doi:10.3117/ plantroot.1.17.

McManmon, M. and Crawford, R.M.M. (1971). A metabolic theory of flooding tolerance: the significance of enzyme distribution and behavior. New Physiol., 70(2):299-306.
McNamara, S.T. and Mitchell, C.A. (1990). Adaptive stem and adventitious root responses of two tomato genotypes to flooding. HortScience, 25 : 100-103.

Mendelssohn, I.A., McKee, K.L. and Patrick, W.H. (1981). Oxygen deficiency in Spartina alterniora roots: metabolic adaptation to anoxia. Science, 214:439-441.

Mielke, M.S., Almeida, A.A.F., Gomes, F.P., Agular, M.A.F. and Mangabeira, P.A.O. (2003). Leaf gas exchange, chlorophyll fluorescence and growth responses of Genipa americana seedlings to soil flooding. Environ. Exp. Bot. (article online):1-11

Mohanty, B. and Ong, B.L. (2003). Contrasting effects of submergence in light and dark on pyruvate decarboxylase activity in roots of rice lines differing in submergence tolerance. Ann. Bot. 91: 291-300.

Monk, L.S., Crawford, R.M.M. and Brandle, R. (1984). Fermentation rates and ethanol accumulation in relation to flooding tolerance in rhizomes of monocotyledonous species. J. Exp. Bot., 35(5):738-745.

Naidoo, G. and Naidoo, S. (1992). Waterlogging responses of Sporobolus virginicus (L.)

Kunth. Oecologia, 90(3):445-450.

Nunez-Elisea, R., Schaffer, B., Fisher, J.B., Colls, A.M. and Crane, J.H. (1999). Influence of flooding on net $\mathrm{CO}_{2}$ assimilation, growth and stem anatomy of Annona species. Ann. Bot. 84: 771-780.

Parelle, J., Brendel, O., Bodénès, C., Berveiller, D., Dizengremel, P., Jolivet, Y. and

Dreyer, E. (2006). Differences in morphological and physiological responses to waterlogging between two sympatric oak species (Quercus petraea [Matt.] Liebl., Quercus robur L.). Ann. Forest Sci., 63:849-859.

Percival, G.C. (2004). Evaluation of physiological tests as predictors of young tree establishment and growth. J. Arbor. 30(2), 80-92.

Percival, G.C. (2005). The use of chlorophyll fluorescence and environmental stress in leaf tissue of tree oak (Quercus) species. J. Arbor. 31(5), 215-227.

Pezeshki, S.R. (1991). Root responses of flood-tolerant and flood-sensitive tree species to soil redox conditions. Trees - Structure and Function, 5:180-186.

Reyna, N., Cornelious, B., Shannon, J.G., Sneller, C.H., (2003). Evaluation of a QTL for waterlogging tolerance in southern soybean germplasm. Crop Sci. 43: 2077-2082.

Stanca A.M., Romagosa, I., Takeda, K., Lundborg, T., Terzi, V. and Cattivelli, L. (2003). Diversity in abiotic stress tolerances. In: von Bothmer R., van Hintum T., Knüpffer H, Sato K, (Eds.), Diversity in Barley (Hordeum vulgare). Elsevier Science BV, Amsterdam, pp. 1-280

Tase, K. and Kobayasi, M. (1992). Studies on flooding tolerance in Italian ryegrass 2 . Simple screening technique for flooding tolerance in Italian ryegrass. Hokuriku Sakumotsu Gak-kaiho, 27: 76-78.

Vasellati, V., Oesterheld, M., Medan, D. and Loreti, J. (2001). Effects of flooding and drought on the anatomy of Paspalum dilatatum. Ann. Bot. 88: $355-360$.

Walter S, Heuberger H, and Schnitzler W.S. (2004). Sensibility of different vegetables of oxygen deficiency and aeration with $\mathrm{H}_{2} \mathrm{O}_{2}$ in the rhizosphere. Acta Horticulturae, 659:499-508.

Wang, S.G., He, L.R., Li, Z.W., Zeng, J.G., Chai, Y.R. and Hou, L. (1996). A comparative study on the resistance of barley and wheat to waterlogging. Acta Agron. Sinica. 22:228-232.

$\mathrm{Xu}, \mathrm{K}$. and Mackill, D.J. (1996) A major gene for submergence tolerance mapped on rice chromosome 9. Mol Breed 2, 219-224.

Yeboah, M.A., Xuehao, C., Feng, C.R., Alfandi, M., Liang, G. and Gu, M. (2008). Mapping quantitative trait loci for waterlogging tolerance in cucumber using SRAP and ISSR markers. Biotech. 7 (2): 157-167. 